\title{
LEGAL ASPECTS OF THE PANAMA SITUATION.
}

Revolutions among Latin-American peoples have become matters of such common occurrence that ordinarily they attract little or no attention from the outside world. Yet such is not the case with the recent and expected revolution upon the Isthmus of Panama. The reason for this is not because of its proportions, but rather because of its relation to the construction of the Panama Canal, and the legal questions which it raises. The revolted territory occupies a commanding position as the gateway between the two great oceans. It is this position which gives to it international importance. With countries as with persons, importance to the world arises not from size but from the possession of something of which the world needs.

This revolution is unlike the average Latin-American revolution of recent years, in that it has adequate justification. The interests of the people of the Isthmus were being senselessly sacrificed to th greed of a ring of unprincipled, blundering politicians from the oppressive effects of whose selfish, shortsighted policy they could see no hope of relief except by a severance of political relations. Political unity is but a means to an end-the promotion of human welfare-and when it fails to meet this end it has outlived its usefulness.

But the question which concerns us more immediately is the justification of the United States for recognizing the organized community in the revolted district as a de facto government, within a few days after their own proclamation of independence. As might be expected, the action of our government has led to no small amount of adverse criticism, both at home and abroad, though by far the greater part of it is at home. It is therefore fitting that we examine it soberly in the light of international law.

While the recognition of a de facto government may be the expression of a wish, it is in law the recognition of a fact. This fact is the existence of a politically organized community having an established seat of government, enforcing obedience to its mandates within its territorial limits in a civilized and orderly manner, 
and asserting its independence, with a reasonable chance of being able to make good its assertion. This does not mean that in case it has hitherto formed a part of another state, all resistance upon the part of the parent state shall have ceased, but that it is reasonably sure that the revolted section will be able to successfully resist such restraining force as said parent state can and will exert in maintaining over them its alleged sovereignty. In other words, the community seeking recognition as a de facto government should have something more than an even chance to live, although the permanency of its existence need not be established beyond all peradventure.

When such a condition of affairs exist, the claimant has, under international law, a right to recognition and other states are not justified in refusing it recognition. But as to the existence of the facts.each state must be its own judge, and, provided it acts in good faith, neither recognition nor the withholding of it is any just cause of complaint, however much its judgment may differ from that of other states. If, however, a state acts in bad faith and extends recognition for the purpose of encouraging resistance to the parent state, such recognition ceases to be the rightful act of a neutral and becomes interference, which might justly be considered as a casus belli. An illustration of this was the recognition of the independence of the United States by France and Holland in I778, which resulted in a declaration of war against both of them by England.

Though recognition does not create a state, it is nevertheless important evidence that a state has been created. Sir James McIntosh and Canning, England's greatest diplomat, have attempted to make a distinction between recognition by the parent state and recognition by other states. To quote the language of the former: "The two senses in which the word recognition is used when applied to the act of the mother country, and when applied to that of third powers are so different as to have nothing very important in common." Canning endorses this view. But the distinction will not hold, for both are simply evidence as to the existence of a fact, and while one may be more conclusive than the other the difference is clearly one of degree rather than of kind.

Perhaps the best statement of the rule is that of John Quincy Adams, quoted with approval by Wharton in his Digest of the International Law, and by Sir William Hall in his most excellent treatise on International Law. "There is a stage in revolutionary 
contests when the party struggling for independence has, I conceive, a right to demand its acknowledgment by neutral parties, and when the acknowledgment may be granted without departure from the obligations of neutrality. It is the stage when independence is established as a matter of fact, so as to leave the chance of the opposite party to recover their dominion utterly desperate. The neutral nation, must, of course, judge for itself when this period has arrived; and as the belligerent nation has the same right to judge for itself, it is very likely to judge differently from the neutral, and to make it a cause or pretext for war, as Great Britain did expressly against France in our revolution, and substantially against Holland. If war results in point of fact from the measure of recognizing a contested independence, the moral right or wrong of the war depends upon the justice and sincerity and prudence with which the recognizing nation took the step."

The length of time during which the revolution has been going on is manifestly a matter of indifference, so long as the necessary results have been accomplished. And in the present case it would seem that the withdrawal of the government forces from the Isthmus, leaving the revolutionists in complete control, was a virtual recognition of their sovereignty by the Colombian government itself, which, coupled with the fact that there is no apparent likelihood that said decadent government will ever be able to re-establish its sovereignty over its revolted subjects, furnishes ample justification for recognition by the United States of the existence of a de facto and also of a de jure government.

In addition to the question of our duty as a neutral state there is raised the legal question of our obligations under the Treaty of Dec. I2, I846, with New Granada. After providing for "most favored nation" treatment with reference to the commerce of the respective countries, reciprocity with regard to tonnage dues and drawbacks, and freedom of transit across the Isthmus to the commerce and citizens of the United States, there is the following provision: "And in order to secure to themselves the tranquil and constant enjoyment of these advantages and as an especial compensation for the said advantages and for the favors they have acquired by the $4^{\text {th }}, 5^{\text {th }}$ and 6 th articles of this treaty. The United States guarantee, positively and efficaciously, to New Granada, by the present stipulation, the perfect neutrality of the before-mentioned Isthmus, with the view that the free transit from the one to the other sea may not be interrupted or embarrassed in any future time 
while this treaty exists; and, in consequence, the United States also guarantee, in the same manner, the rights of sovereignty and property which New Granada has and possesses over the said territory."

The fact that New Granada no longer exists does not affect our obligations under the treaty, as it is a well established rule of international law that a change of name by a state does not affect its treaty rights or obligations. This treaty is still in force and we have in accordance with its provisions, sometimes at the request of the Colombian government and sometimes upon our own initiative, used force, to maintain the free transit of the Isthmus. And in so doing we have performed a valuable service to Colombia, to the world and to our own citizens. Until the treaty is abrogated, there is no question as to our legal or moral right to protect and enforce freedom of transit on the Isthmus whether by rail or any other means of transportation.

But the question has been raised as to our obligation to protect the sovereignty of Colombia against revolution by her own citizens. The terms of the treaty give some color to the view of those who hold that we are under such obligation. The question is one of interpretation. And in interpreting a treaty, as in interpreting a contract between individuals, we must look to the intention of the parties; for a treaty is nothing but a contract to which independent states are parties. In arriving at the intention of the parties, we must take into account the circumstances existing at the time the contract was made and with reference to which both the parties contracted. In the present case there can be no doubt as to the purpose of entering into the treaty. The intention of the parties was clearly not to protect the Colombian sovereignty against the people of the Isthmus, but rather to guarantee it against interference upon the part of European powers from whom there was at that time reason to apprehend danger. The United States has never entered into a treaty for the purpose of compelling a people to submit to a sovereignty which disregarded their welfare, nor is there any evidence that at the time the treaty was entered into the other party to it intended that we should ever be called upon to protect their sovereignty against anything except outside interference. Hence, though the literal terms of the treaty would give us authority to use force if necessary in order to prevent the people of the Isthmus from establishing their sovereignty over it, such a construction would undoubtedly do violence to the spirit of the treaty. 
An excellent precedent for construing a treaty according to the spirit rather than the letter is the case of the Treaty of Utrecht, cited by Phillimore for this purpose. According to the provisions of the treaty, France was to destroy the fortifications of Dunkirk and never to rebuild them. She complied with her treaty engagements by destroying the fortifications of the port of Dunkirk, but immediately began the forming and fortifying of the port of Mardyck, scarcely a league away. England protested against such an evasion of the treaty and France finally admitted that her interpretation, though not precluded by the letter of the treaty, was unsound.

The recognition of a new state created by revolution against the parent state is always more or less of a delicate nature and very likely to excite opposition unless it follows a formal recognition by said parent state. But the recognition of the New Republic of Panama by the United States has contravened no principle of international law, and the conduct of our government, for which Secretary Hay is largely responsible, has throughout the proceedings been characterized by frankness, tact, and a statesmanlike grasp of the situation.

Edwin Maxey. 